INOBIS: Jurnal Inovasi Bisnis dan Manajemen Indonesia Volume 04, Nomor 04, September 2021

Mochamad Soelton, Eko Tama Putra Saratian, Aji Erlangga, Harefan Arief

Yeni Kamalia, Tantri Yanuar Rahmat Syah, Irfan Noviandy Aulia

\title{
Organizational Citizenship Behavior, What Does Really Matter?
}

\author{
Mochamad Soelton \\ Mercu Buana University, Jakarta - Indonesia \\ Eko Tama Putra Saratian \\ Mercu Buana University, Jakarta - Indonesia \\ Aji Erlangga \\ Institute of Technology and Business Ahmad Dahlan, Tangerang - Indonesia \\ Harefan Arief \\ Mercu Buana University, Jakarta - Indonesia \\ Yeni Kamalia \\ Mercu Buana University, Jakarta - Indonesia \\ Tantri Yanuar Rahmat Syah \\ Esa Unggul University, Jakarta - Indonesia \\ Irfan Noviandy Aulia \\ Mercu Buana University, Jakarta - Indonesia \\ Email: soelton@mercubuana.ac.id
}

\begin{abstract}
Human resources management is currently a necessity and is no longer an option if a company wants to grow. Human Resources is very important in an organization, because the effectiveness and success of an organization is very dependent on the quality and performance of the human resources that exist in the organization. This study aims to examine and analyze the influence of Political Organization, Organizational Climate, and Organizational Culture on Organizational Citizenship Behavior (OCB) with Job Satisfaction as an intervening variable at PT. Pegadaian Indonesia (PERSERO). The object of this research is the employees as many as 80 respondents. The approach used in this research is the Component or Variance Based Structural Equation Model with Smart-PLS analysis tools. The results showed that the Political Organization had no significant effect on Job Satisfaction on the employees, Organizational Climate has a significant positive effect on Job Satisfaction, Organizational Culture has a significant positive effect on Job Satisfaction, Political Organizational significant positive effect on Organizational Citizenship Behavior on employees, Organizational Climate has a significant positive effect on Organizational Citizenship Behavior for employees, Organizational Culture significantly positive effect on Organizational Citizenship Behavior on employees, Job Satisfaction has a significant positive effect on Organizational Citizenship Behavior.
\end{abstract}

Keywords : Organizational Culture, Organizational Citizenship Behavior, Job Satisfaction Political Organization, Organizational Climate,

\section{Introduction}

In the current era of globalization, competition between companies is getting tougher, because companies are not only faced with domestic competition, but also abroad. Facing 
these situations and conditions, companies must determine their management strate gies and policies, particularly in the field of human resources (HR). HR management is currently a necessity and is no longer an option if a company wants to grow. Human Resources is very important in an organization, because the effectiveness and success of an organization is very dependent on the quality and performance of the human resources that exist in the organization. High performance of human resources (employees) will encourage the emergence of job satisfaction. Job satisfaction is the result of employees' perceptions of how well their work provides things that are considered important (Luthans, 2009).

(Rivai \& Mulyadi, 2012) state that job satisfaction is an assessment of workers about how far their overall job satisfies their needs. Employee performance is considered good enough so that many customers are happy and feel satisfied with the service provided at the company PT. Pegadaian (PERSERO). With a high level of customer satisfaction, it directly affects job satisfaction for these employees. So in general, a positive attitude is reflected in the feelings of employees about their work. Employee actions lead to personal interests without paying attention to the interests of other employees and the most important thing is to get more attention in front of the leadership of the organization, so it is very rare to find an attitude of initiative to help voluntarily in the organization. With this it can be concluded that organizational politics is a phenomenon that occurs at PT. Pegadaian (PERSERO). Organizational politics is seen as objective behavior through investigating political tactics. Organizational political behavior tactics have no sanctions, which may be detrimental to organizational goals or to the interests of others in the organization (Harrell-Cook et al., 1999). So that organizational politics makes it possible to produce positive and negative work (Fairuzzabadi, Murkhana, \& Ayu, 2016).

In addition to the problems that exist in the employees of PT. Pegadaian (PERSERO) is an employee who does not always take work and organization seriously, earning $70 \%$. This shows that this behavior has become a special concern because it will hinder the running of work in the company in achieving company goals. An attitude of not being serious about work influences employees to take an attitude of mutual cooperation between members within the organization. In this case, the relationship between employees will have an impact on the occurrence of cracks in the organization, so that employees tend to take action just to work and take the organization seriously. Based on previous research conducted by (Soelton \& Nugrahati, 2018; Soelton et al., 2020; Ramli et al., 2019; Gunawan \& Santosa, 2012), organizational politics has an influence on how employees perceive their organizations .

\section{Method}

The process of this study begins with the activities of problems identifying at the research site, conducting problem formulation and gathering basic theories to strengthen the foundation of each variable. Furthermore, the preparation of methods in data collection, instrument preparation and testing techniques are carried out. Seeing the characteristics of the existing population and the purpose of this study, the sampling technique in this study is saturated sampling, namely the determination of respondents from the all of population.

In this study using a quantitative approach in which the survey through a questionnaire method using the Partial Least Square (PLS) methodology and descriptive analysis using SPSS Statistics 25. The population in this study is the all employes who work at PT. Pegadaian (PERSERO) with a total population of 80 respondens. 


\section{Literature Review}

\section{Organizational Citizenship Behaviour (OCB)}

Organizational Citizenship Behavior (OCB) is behavior that arises at the discretion of an employee which is done voluntarily and without coercion. This behavior goes beyond the formal demands of a job or a formal job description Smith in Andriani (2012) and the role of OCB (Organizational Citizenship Behavior) is one of the factors that most determines the success of a company (Jumadi, Soelton, \& Nugrahati, 2018).

\section{Job Satisfaction}

According to Sutrisno (2011) job satisfaction is a pleasant or unpleasant emotional state for employees to view their work. Meanwhile, according to Suhendi \& Anggara (2010) job satisfaction is a (positive) attitude of workers towards their work, which arises based on an assessment of the work situation. Furthermore, (Badriyah, 2015) argues that the definition of job satisfaction according to Mila Badriyah is the attitude or feelings of employees towards pleasant or unpleasant aspects of work in accordance with the assessment of each employee.

\section{Political Organizational}

According to (Sunyoto \& Burhanudin, 2011) organizational politics can be defined as an increase in self-interest done on purpose. Organizational politics involves actions to influence that are done intentionally to increase or protect the personal interests of individuals or groups. Individuals who join an organization are faced with a choice, namely pursuing personal interests or achieving organizational goals. Meanwhile, according to (Siswanto, 2007) organizational politics is any actor or group in the organization to build power to influence the goal setting, criteria or organizational decision-making process in order to fulfill its interests.

\section{Organizational Climate}

According to (Wirawan, 2007) Organizational climate is the perception of organizational members (individually and in groups) and those who are constantly in touch with the organization (for example suppliers, consumers, consultants, and contractors) regarding what exists or happens in the organization's internal environment on a regular basis that affects attitudes to organizational behavior and performance of organizational members which then determine organizational performance. (Tagiuri and Litwin, 1968) define organizational climate as the quality of the organization's internal environment which is relatively continuous experienced by members of the organization and can be described in terms of a set of characteristics of the nature of the organization.

\section{Organizational Culture}

(Schein, 2010) states that organizational culture is an archetype accepted by organizations to act and solve problems, form employees who are able to adapt to the environment and unite organizational members. Organizational culture according to (Wirawan, 2007) is norms, values, assumptions, beliefs, philosophy, organizational habits, etc., founders, leaders and members of the organization are socialized and taught to new members and applied in organizational activities so as to influence mindsets, attitudes. and the behavior of organizational members in serving consumers, and achieving organizational goals. 


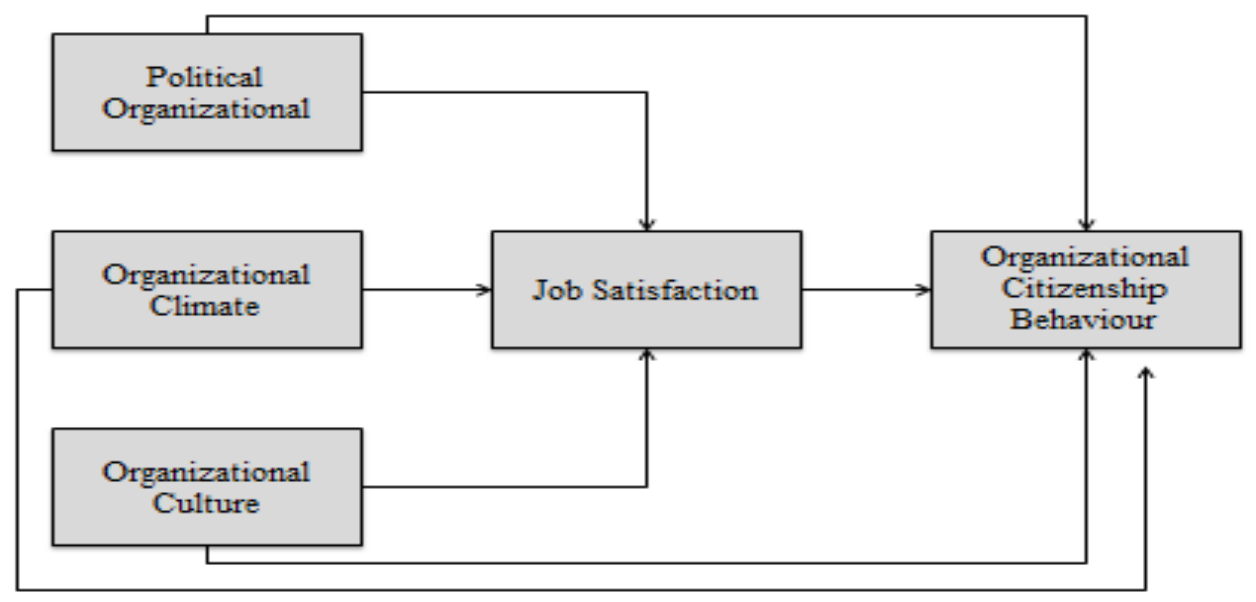

Figure 1: Research Framework

\section{Discussion}

\section{Results}

Seeing the $\mathrm{R}$ Square value $\left(\mathrm{R}^{2}\right)$ which is a testing for Goodness of Fit (GoF) Model. In assessing models with PLS begins to see $R$ Square $\left(R^{2}\right)$ for each dependent latent variables. According to Chin (1998), the values of $\mathrm{R}$ square are 0,67 (strong), 0.33 (moderate) and 0.19 (weak). The relevance of the predicted value (Q squared) at 0,02 (small), 0.15 (medium) and 0.35 (large). Testing Goodness of Fit Structural models in the inner model using predictive relevance $\left(\mathrm{Q}^{2}\right)$. Q-Square $\left(\mathrm{Q}^{2}\right)$ value greater than 0 (zero) indicates that the model has a predictive relevance value.

The measurement model analysis in this case aims to test the validity and reliability of each dimension and the indicators used to measure each of the previously constructed variables. Analysis of the measurement model can be explained by explaining the discriminant validity value by looking at the square root value of Average Variance Extracted (AVE) with a suggested value above 0.5 , loading factor $(>0.5)$, building validity and composite reliability (Cronbach's Alpha> 0.70).

Table 1: Goodness of Fit Model (GoF)

\begin{tabular}{|c|c|c|c|c|}
\hline Variable & AVE & $\begin{array}{l}\text { Composite } \\
\text { Reliability }\end{array}$ & $\begin{array}{c}\text { Cronbac's } \\
\text { Alpha }\end{array}$ & $\begin{array}{c}\text { R } \\
\text { Square }\end{array}$ \\
\hline Political Organizational & 0,763 & 0,899 & 0,743 & - \\
\hline Organizational Climate & 0,844 & 0,746 & 0,816 & - \\
\hline Organizational Culture & 0,690 & 0,712 & 0,893 & - \\
\hline Job Satisfaction & 0,734 & 0,866 & 0,757 & 0,855 \\
\hline $\begin{array}{l}\text { Organizational } \\
\text { Citizenship Behavior } \\
\text { (OCB) }\end{array}$ & 0,751 & 0,709 & 0,786 & 0,817 \\
\hline
\end{tabular}

The $\mathrm{R}^{2}$ value indicates that the criteria are strong, it is concluded that the proposed model is supported by empirical research in which the model is classified as an appropriate model. 
The AVE values are $>0.5$, which indicates the variables in the meet of the model of discriminant validity criteria. The composite reliability and Cronbach's Alpha value for each variable is $>0.70$ which means all variables are classified as reliable.

Table 2: Loading Factor Between Latent Variables and Dimensions

\begin{tabular}{lccc}
\hline Variable & Indicator & Loading Factor $(\boldsymbol{\lambda})$ & Remark \\
\hline Political Organizational & P1 & 0,587 & Valid \\
& P3 & 0,783 & Valid \\
& P4 & 0,855 & Valid \\
\hline \multirow{4}{*}{ Organizational Climate } & P6 & 0,609 & Valid \\
& O1 & 0,663 & Valid \\
& O2 & 0,836 & Valid \\
& O4 & 0,599 & Valid \\
\hline \multirow{5}{*}{ Organizational Culture } & O7 & 0,803 & Valid \\
& OC1 & 0,655 & Valid \\
& OC2 & 0,698 & Valid \\
& OC3 & 0,711 & Valid \\
\hline \multirow{5}{*}{ Job Satisfaction } & OC5 & 0,689 & Valid \\
& J1 & 0,845 & Valid \\
& J2 & 0,769 & Valid \\
& J3 & 0,598 & Valid \\
\hline \multirow{3}{*}{$\begin{array}{l}\text { Organizational Citizenship } \\
\text { Behavior (OCB) }\end{array}$} & J4 & 0,896 & Valid \\
& OCB1 & 0,866 & Valid \\
\cline { 2 - 4 } & OCB4 & 0,748 & Valid \\
& OCBB5 & 0,871 & Valid \\
& OCBB6 & 0,690 & Valid \\
\hline & OCBB9 & 0,845 & Valid \\
\hline
\end{tabular}

The measurement results based on analysis of data processing on dimensional models based indicators show that the overall indicator is processed on top of that is in Table 2 were classified as invalid where the majority of value loading factor greater than $>0,50$ (over 0,50 ).

Table 3: The Result of Hypothesis Testing

\begin{tabular}{lcccc}
\hline Hypothesis & $\begin{array}{c}\text { Original } \\
\text { Sample }\end{array}$ & $\boldsymbol{\gamma} \boldsymbol{\beta}$ & $\begin{array}{c}\text { T- } \\
\text { Statistics }\end{array}$ & Remark \\
\hline $\mathbf{P} \rightarrow \mathbf{J}$ & 0,588 & 0.078 & 4.109 & Positive - Significant \\
$\mathbf{O} \rightarrow \mathbf{J}$ & 0,421 & 0.056 & 3.992 & Positive - Significant \\
$\mathbf{O C ~} \rightarrow \mathbf{J}$ & 0,437 & 0.074 & 2.801 & Positive - Significant \\
$\mathbf{P} \rightarrow$ OCB & 0,309 & 0.044 & 3.129 & Positive - Significant \\
$\mathbf{O} \rightarrow$ OCB & 0,335 & 0.063 & 4.073 & Positive - Significant \\
$\mathbf{O C ~} \rightarrow$ OCB & 0,490 & 0.050 & 4.904 & Positive - Significant \\
$\mathbf{J ~} \rightarrow$ OCB & 0,510 & 0.076 & 5.280 & Positive - Significant \\
\hline
\end{tabular}




\section{Discussion}

\section{The influence of political organizational towards job satisfaction}

Regarding the testing of hypothesis, the results obtained t-statistic political organizational of job satisfacyion of 4.109 and the value of the original sample of 0.588 . T-statistic value is more substantial than the value of the t-table is 1.96 and the value of the original sample shows the value positive, the result describes that influential political organizational positive and significant impact on job satisfaction. Positive values in the original sample indicate the direction of a positive relationship between the political organizational on job satisfaction. The results of this research are supported by research (Fairuzzabadi, Murkhana, \& Ayu, 2016).

\section{The influence of organizational climate towards job satisfaction}

Regarding the hypothesis test the impact of the organizational climate on job satisfaction obtained the value of t-statistic 3.992 and the original sample value 0.421 . The value of $t-$ statistic > the t-table value that is 1.96 and the value of original sample indicates the value positive, this result shows that organizational climate is influential significant positively impact on job satisfaction. The results of this study are supported by research (Ariyani, 2012), (Wibisono, 2011), (Susanti, 2012).

\section{The influence of organizational culture towards job satisfaction}

Organizational cultur is influential positive and significant to job satisfaction. Obtained the t-statistic value of 2.801 and the value of original sample of 0.437 . The t-statistic value $>$ the t-table value that is 1.96 and the value of original sample indicates positive, this result shows that organizational culture is influential positive and significant impact on job satisfaction. The results are supported by (Husodo, 2018), (Badawy, Kamel, \& Mahdy, 2016).

\section{The influence of political organizational towards organizational citizenship behaviour}

Furthermore, based on the hypothesis testing the effect of political organizational on organizational citizenship behaviour the results obtained value of t-statistic 3.129 and the value of original sample 0.309 . The $t$-statistic value $>t$-table value that is 1.96 and the value of original sample indicates the posotive, this result shows that influential political organizational positive and significant impact on organizational citizenship behaviour. The results of this study are supported by (Pradana \& Triwijyati, 2016)

\section{The influence of organizational climate towards organizational citizenship behaviour}

Furthermore, regaring the hypothesis testing the effect of organizational climate on organizational citizenship behaviour the results obtained value of t-statistic 4.037and the value of original sample 0.335 . The t-statistic value > the t-table value that is 1.96 and the value of original sample indicating the positive, result shows influential organizational climate positive and significant impact on organizational citizenship behaviour. Based on the results of (Suifan, 2016).

\section{The influence of organizational culture towards organizational citizenship behaviour}

Furthermore, regarding the hypothesis testing the effect of organizational culture on organizational citizenship behavior the results obtained value of t-statistic 4.904 and the value of original sample 0.490 . The t-statistic value > the t-table value that is 1.96 and 
the value of original sample indicating the positive value, result shows influential organizational culture significantly positive impact on organizational citizenship behaviour. Based on the results of (Badawy, Kamel, \& Mahdy, 2016).

\section{The influence of job satisfaction towards organizational citizenship behaviour}

Furthermore, regarding the hypothesis testing the effect of job satisfaction on organizational citizenship behaviour the results obtained value of t-statistic 5.280 and value of the original sample 0.510 . The t-statistic value $>$ the t-table value that is 1.96 and the value of original sample indicating the positive value, result shows that influential job satisfaction have significantly positive impact on organizational citizenship behaviour. Based on the results of (Pradhiptya, 2013).

\section{Conclusion}

The aim of this research is to analyze The Effect Of Political Organization, Organizational Climate And Organizational Culture On Organizational Citizenship Behaviour (OVB) With Job Satisfaction As Intervening Variables of PT. Pegadaian (PERSERO). Based on the analysis of the data and the discussion that has been put forward, it can be stated several research conclusions as follows:

1. Political Organizational has a significantly positive effect on Job Satisfaction at PT. Pegadaian (PERSERO). This means that if the political organization in a company is good, then the level of job satisfaction of employees will be increase.

2. Organizational Climate has a significantly positive effect on Job Satisfaction of PT. Pegadaian (PERSERO). This means that if the orgnanizational climate in a company is low or bad, the level of job satisfaction of employees will also be higher.

3. Organizational Culture has a significantly positive effect on Job Satisfaction of PT. Pegadaian (PERSERO). This means that if a organization culture in a company is going well, then the level of job satisfaction of employees is also getting higher.

4. Political Organizational has a significantly positive effect on Organizational Citizenship Behaviour of PT. Pegadaian (PERSERO). This means that if the political organization in a company is good, then the level of organizational citizenship behaviour in a company is also high.

5. Organizational Climate has a significantly positive effect on Organizational Citizenship Behaviour of PT. Pegadaian (PERSERO). This means that if the organization climate in a company is good, then the level of organizational citizenship behaviour in a company will also be good.

6. Organizational Culture has a significantly positive effect on Organizational Citizenship Behaviour of PT. Pegadaian (PERSERO). This means that if a organization climate in a company is good, then the level of organizational citizenship behaviour in a company will also be good.

7. Job satisfaction has a significantly positive effect on Organizational Citizenship Behaviour of PT. Pegadaian (PERSERO). This means that if the level of job satisfaction of employees in a company is high, then the level of organizational citizenship behaviour in a company will also be good. 


\section{Implication}

The study of this research has concluded both of theoretical and practical implications:

1. Companies are fairer in determining or placing positions for each employee, so that each employee can work well if the career path in a company can be fair and pay attention to the environment around the employee's work and can carry out maintenance or repairs, so that employees feel comfortable at work.

2. Companies to be able to share duties or workloads fairly among each of its employees, it does not differentiate from any aspect, including the culture of the employees and pay the salaries of each employee fairly according to the class or level of work load and difficulty received by employees, so that employees work actively and feel entitled which he received in accordance with the load done.

3. Companies are able to divide the work of each employee according to their portion so that employees do not feel burdened at work and feel treated fairly.

\section{Limitation}

This research may not cover all variables and issues that might be encountered by the organizational citizenship behaviour. So that in the future, if there are researchers who want to examine organizational citizenship behaviour, they can use other variables outside of this study with a wider area of respondents and others companies.

\section{References}

Ariyani, E. D. (2012). Dampak Iklim Organisasi terhadap Kepuasan Kerja. Manajerial, Vol.11, No.21, 132-149.

Badawy, E., Kamel, M., \& Mahdy. (2016). Exploring the Relationship between Organizational Culture, Job Satisfaction and Organizational Citizenship Behavior. International Journal of Human Resource Studies, Vol.6, No.4, 20-33.

Badriyah, M. (2015). Manajemen Sumber Daya Manusia, Cetakan 1. Bandung: CV Pustaka Setia.

Fairuzzabadi, Murkhana, \& Ayu, M. P. (2016). Pengaruh Politik Organisasional pada Kepuasan Kerja : Kepercayaan dan Dukungan Sosial sebagai Permoderasi. Jurnal Manajemen dan Inovasi, Vol.7, No.1, 1-23.

Gomes. (2010). Manajemen Sumber Daya Manusia. Yogyakarta: Andi Offset.

Green, \& al, e. (2013). “Is Job Quality Becoming More Unequal?”. Industrial and Labor Relations Review, Vol.66, No.4. 753-784.

Hasibuan, M. (2012). Manajemen Sumber Daya Manusia. Jakarta: PT Bumi Aksara.

Husodo, Y. R. (2018). Pengaruh Budaya Organisasi terhadap Organizational Citizenship Behaviour (OCB) dan Kepuasan Kerja Sebagai Variabel Intervening pada PT. Jatim Indo Lestari. Agora, Vol.6, No.1, 1-8.

Jumadi, Soelton, M., \& Nugrahati, T. (2018). Bagaimanakah Beban Kerja dan Stress Kerja Mempengaruhi Organizational Citizenship Behaviour (OCB) dan Kinerja Karyawan PT. Multitek Indopanca Jakarta. Forum Manajemen Indonesia, 501.

Kasmir. (2016). Manajemen Sumber Daya Manusia (Teori dan Praktik). Jakarta: PT. Raja Grafindo Persada.

Luthans, F. (2009). Perilaku Organisasi, Edisi Sepuluh. Yogyakarta: Penerbit Andi. 
Mangkunegara, A. (2015). Manajemen Sumber Daya Manusia Perusahaan, Cetakan Kedua Belas. Bandung: PT. Remaja Rosda Karya.

Mobley, W. (2011). Pergantian Karyawan Sebab Akibat dan Pengendaliannya. Jakarta: Pustaka Binaman Pressindo.

Pradana, A. F., \& Triwijyati, D. (2016). Pengaruh Politik Organisasi dan Komitmen Organisasi terhadap Organizational Citizenship Behaviour Karyawan Koperasi Karyawan (KOPKAR) Sampoerna Surabaya. Jurnal Ilmu Manajamenen, Vol.4, No.2, 101-111.

Pradhiptya, A. R. (2013). Pengaruh Kepuasan Kerja terhadap Organzational Citizenship Behaviour (OCB) dengan mediasi Komitmen Organisasional. Jurnal Bisnis dan Manajemen, Vol.6, No.1, 50-58.

Rivai, V. (2011). Manajemen Sumber Daya Manusia Untuk Perusahaan Dari Teori ke Praktik. Jakarta: Raja Grafindo Persada.

Rivai, V., \& Mulyadi, D. (2012). Kepemimpinan dan Perilaku Organisasi. Jakarta: Rajawali Pers.

Schein, E. (2010). Organizational Culture and Leadership. San Fransisco: Jossey-Bass Publisher.

Sedarmayanti. (2013). Manajemen Sumber Daya Manusia. Bandung: Refika Aditama.

Septiari, N. K., \& Ardana, I. K. (2016). Pengaruh Job Insecurity dan Stres Kerja Terhadap Turnover Intention Karyawan Pada Hotel Asana Agung Putra Bali. Jurnal Manajemen Unud, Vol. 5, No. 10.

Siswanto. (2007). Politik Dalam Organisasi : Suatu Tinjauan Menuju Etika Berpolitik. Jurnal Manajemen, Vol.10, No.4, 159-165.

Soelton, M., \& Atnani, M. (2018). How Work Environment, Work Satisfaction,Work Stress on the Turnover Intention Affect University Management. Jurnal Manajemen Bisnis Indonesia, Vol.5, No.3.

Soelton, M., Mohammed Hokroh, Eko Tama Putra Saratian, Tati Nugrahati, Aulia Putra, Tine Yuliantini, Febry Nur Fauzy, Miftahuddin M. Sidik. 2020. Exploring Factors That Influence Work Engagement in Social Welfare Institution at Gayo Lues Atjeh Indonesia. American International Journal of Business Management (AIJBM) ISSN2379-106X, www.aijbm.com Volume 3, Issue 10 (October 2020), PP 46-58

Soelton, M., Marco Suatoni, Tantri Yanuar Rahmat Syah, Yanto Ramli, Puji Santoso, Bella Amanda and Rini Octaviani, 2020. Conceptualizing The Role of Organizational Commitment. American International Journal of Business Management (AIJBM). ISSN- 2379-106X, www.aijbm.com. Volume 3, Issue 8 (August 2020), PP 178-188.

Soelton, M., Irfan Noviandy Aulia, Inge Hutagalung, Tantri Yanuar Rahmat Syah, Silvi Kurniasari. 2020. Recognizing How The Burnouts and Acuted Stress Affects Turnover Intention in The Stationary Industry. International Journal of Economics, Commerce and Management. United Kingdom, ISSN 2348 0386, Vol. VIII, Issue 6, June 2020.

Soelton, M., Noermijati Noermijati, Fatchur Rohman, Mugiono, Irfan Noviandy Aulia and Rustam Efendi Siregar. 2020. Reawakening perceived person organization fit and perceived person job fit: Removing obstacles organizational commitment. Management Science Letters Vol. 10 Issue 13 (2020) 2993-3002 homepage: www.GrowingScience.com/msl

Soelton, M., Noermijati Noermijati, Inge Hutagalung, Nicko Gana Saputra, Suprapto, Sonia Tiffany. (2020). What is the Role of Women When Faced with Personal Conflicts at Work?. European Journal of Business and Management. Vol.12, No.14, 2020 
www.iiste.org ISSN 2222-1905 (Paper) ISSN 2222-2839 (Online). DOI: 10.7176/EJBM/12-14-01

Soelton, M., Noermijati Noermijati, Nicko Alexander Vizano, Yenida Parmariza, Yudha B. Abadi, Shandra Zulfriadi. (2020). Recognizing the Role of Job Satisfaction in Predicting the Relationship Between Political Organization, Organizational Climate, and Organizational Culture on Organizational Citizenship Behaviour on Liquor Distributor Companies in Indonesia. European Journal of Business and Management. Vol.12, No.13, 2020 www.iiste.org ISSN 2222-1905 (Paper) ISSN 2222-2839 (Online) 72. DOI: 10.7176/EJBM/12-14-01

Soelton, M., Yudha B. Abadi Nicko Gana Saputra Eko Tama Putra Saratian Harefan Arief, Devi Haryanti. 2020. Factors affecting turnover intention among waiters in franchise restaurants. South East Asia Journal of Contemporary Business, Economics and Law, Vol. 21, Issue 5 (April) ISSN 2289-1560 2020126

Soelton, M., Eko Tama Putra Saratian Anees Janee Ali Tine Yuliantini Dwi Astari. 2020. The implication of emotional environment that may effect the employee turnover intention. South East Asia Journal of Contemporary Business, Economics and Law, Vol. 21, Issue 5 (April) ISSN 2289-1560 2020108

Soelton, M., Eko Tama Putra Saratian Anees Janee Ali Sri Anah Immanuel Alfe Andre Yosef. 2019. Implementation of organizational commitment in engineering and construction industries. South East Asia Journal of Contemporary Business, Economics and Law, Vol. 20, Issue 5 (DEC) ISSN 2289-1560 2019167

Soelton, M., Yanto Ramli, Anees Janee Ali Harefan Arief, Eko Tama Putra Saratian Eviyanti Pasaribu. 2020. To imply the organizational citizenship behavior in the work place to improve employee performance. International Journal of Business, Economics and Law, Vol. 21, Issue 5 (April) ISSN 2289-1552 202070.

Soelton,M., Nicko Alexander Visano, Irfan Noviandy Aulia, Mugiono, Tantri Yanuar Rahmat Syah Lecturer, Siti Annisa Febriyani. 2020. Work Insecurity Enhances Work Stress and Burnout in Indonesian Railway Industry. THE INTERNATIONAL JOURNAL OF BUSINESS \& MANAGEMENT. Vol. 8 Issue 4 April, 2020 ISSN 2321-8916 www.theijbm.com

Soelton, M., Nicko Alexander Visano, Irfan Noviandy Aulia, Mugiono, Bayu Hatmo Purwoko, Tantri Yanuar Rahmat Syah, Nonni Hastuti. 2020. The Impact of Employee's Commitment and Personality That Influence Their Organizational Citizenship Behavior in Property Industry. THE INTERNATIONAL JOURNAL OF BUSINESS \& MANAGEMENT. ISSN 2321-8916 www.theijbm.com 232 Vol 8 Issue 4 DOI No.: 10.24940/theijbm/ 2020/v8/i4/BM2004-055 April, 2020

Mobley, W. (2011). Pergantian Karyawan Sebab Akibat dan Pengendaliannya. Jakarta: Pustaka Binaman Pressindo.

Rivai, V. (2011). Manajemen Sumber Daya Manusia Untuk Perusahaan Dari Teori ke Praktik. Jakarta: Raja Grafindo Persada.

Sedarmayanti. (2013). Manajemen Sumber Daya Manusia. Bandung: Refika Aditama.

Septiari, N. K., \& Ardana, I. K. (2016). Pengaruh Job Insecurity dan Stres Kerja Terhadap Turnover Intention Karyawan Pada Hotel Asana Agung Putra Bali. Jurnal Manajemen Unud, Vol. 5, No. 10.

Soelton, M., P Amaelia, H Prasetyo. 2020. Dealing with Job Insecurity, Work Stress, and Family Conflict of Employees. 4th International Conference on Management, Economics and Business (ICMEB 2019). 2020/2 (167-174). atlantis-press.com 
Soelton, M., S Himawan, L Fazriyanti, S Ria, I Gustiawan. 2018. Visionary Leadership Structure: Stress Levels On Performance In Technology and Communications Industry. Forum Manajemen Indonesia 10-Palembang. 10 (November 2018), 508

Soelton, M., S Ria, F Arifin. 2018. Effect of Organizational Culture, Job Satisfaction, and Engagement on Employee Performance in Government Company. Proceeding International Conference on Management Economics and Business of Universitas Mercu Buana (ICMEB 2018). Jilid 2018. ISBN 978-979-99488-3-0

Soelton, M., L Yuliana. 2018. Effect of Organizational Culture, Organization Commitment, and Work Loyalty on Employee Performance in Manufacture Industry. Proceeding International Conference on Management Economics and Business of Universitas Mercu Buana (ICMEB 2018). Jilid 2018. ISBN 978-979-99488-3-0

Soelton, M., A Daryadi. 2018. Effect on Compensation, Work Environment, Education, and Training on Employee Performance or Coffee Bean Outlets in Jakarta. Proceeding International Conference on Management Economics and Business of Universitas Mercu Buana (ICMEB 2018). Jilid 2018. ISBN 978-979-99488-3-0

Soetopo, H. (2012). Perilaku Organisasi. Bandung: PT Remaja Rosdakarya.

Sunyoto, D., \& Burhanudin. (2011). Perilaku Organisasional, edisi pertama. Yogyakarta: CAPS.

Susanti, E. (2012). Pengaruh Iklim Organisasi terhadap Kepuasan Kerja dan Komitmen Karyawan pada Universitas Terbuka. Jurnal Organisasi dan Manajemen, Vol.8, No.2, 121-134.

Wibisono, A. (2011). Pengaruh Iklim Organisasi terhadap Kepuasan Kerja studi tentang Pengaruh Iklim Organisasi terhadap Kepuasan Kerja Pegawai Puskesmas Turen di Malang. Jurnal Aplikasi Manajemen, Vol.9, No.3, 1000-1010.

Wijayanti, P. S. (2012). Hubungan Antara Job Insecurity dan Konflik Peran dengan Performansi KerjaKaryawan di Balai Besar Wilayah Sungai Bengawan Solo. Jurnal Ilmiah Psikologi Candrajiwa, Vol.1, No.3.

Wirawan. (2007). Budaya Organisasi dan Iklim Organisasi : Teori Aplikasi dan Peneitian. Jakarta: Salemba Empat. 